but very few of the patients had derived benefit from it. Most were made worse, and some complained rather vehemently. It was suspicious that a considerable number of the patients so treated did not appear a second time. Either their disease was cured off-hand, or they were so little enamoured of the permanganate that they declined a second trial. A variety of urethral syringes were shown, those of unsuitable pattern being pointed out, and the mode of instructing patients in their use described. A new one, constructed by Mr. Hawkesley, of Blenheim-street, Bondstreet, for patients to carry in the pocket, with a small supply of lotion, was shown. It resembles a funnel-shaped drop bottle, about three inches long, terminating in a nozzle below, and closed by an india-rubber diaphragm above. The syringe is easily filled and emptied by alternately depressing and elevating the thumb on the elastic cover, and about two drachms can thus be drawn from a bottle and thrown into the urethra in a few moments. The limited trial to which this syringe has been yet put makes it necessary to speak with caution, but it has proved very useful in several patients' hands. After describing the leading concomitants or consequences of urethritis, Mr. Hill concluded by warning his hearers not to suppose that every case of gonorrhœa, either in men or women, was set up by a specific contagion. Perhaps ninety out of every hundred are so; but the most efficient predisposing cause-one seldom absent in those affected-was any violent irritation of the urethra, such as prolonged sexual excitement, alcoholic excess, and particulariy the use of so-called "preventive" injections immediately after coitus. This was stigmatised as a very dangerous procedure. With such predisposing causes urethritis might arise from contamination with almost any disordered vaginal discharge without any specific contagion.

\section{A CASE OF PERINEAL PERFORATION DURING LABOUR.}

\section{BY FRANK ARGLES, L.R.C.P., M.R.C.S.}

ON March $23 \mathrm{rd}$ I was called at 8.30 A.m. to attend Mrs.G-, aged twenty-eight, in her first confinement. I found, upon examining her, that the head was pressing firmly upon the perineum, and the membranes were slightly protruding; the external parts were very small. The pains were good and regular, occurring about every two minutes; but they seemed in no way to dilate the external parts. In half an hour the membranes ruptured. I supported the perineum well throughout the case, and after being with my patient about an hour I found that the head had passed through the posterior wall of the vagina, and the face was presenting itself through an artificial opening in the perineum, just anterior to the anus, between it and the vagina, and without injuring the bowel. This false passage was, of course, with each pain getting larger. Feeling confident that the child must be born eventually through this opening, after consultation with Dr. Hawkes, I passed a director down the natural passage, between it and the child's head, and slit it up for an jnch and a half. In less than a minute a living female child was born. I ordered the bowels to be kept quiet for the first five days after delivery, and then a gruel enema to be administered. Warm-water cloths were from the commencement applied to the injured parts. On April 12th the wound was entirely healed, and my patient was able to walk downstairs.

Wanstead, E., April, 1871.

UNIVERSITY of LONDON.-At a meeting of the Senate of the University of London, on Wednesday, the 26 th inst., the following gentlemen were elected examiners for the medical degrees during the ensuing year:- In Medicine: Dr. Bristowe and Dr. Russell Reynolds. In Surgery : Profs. John Birkett and John Marshall. In Anatomy: Profs. John Wood and G. V. Ellis. In Physiology: Prof. Michael Foster and Mr. Henry Power. In Obstetric Medicine: Dr. Barnes and Prof. Graily Hewitt. In Materia Medica: Dr. Fraser and Prof. Garrod. In Forensic Medicine: Dr. Headlam Greenhow and Dr. Thomas Stevenson.
Af iflirror

OF THE PRACTICE OF

\section{MEDICINE AND SURGERY IN THE}

HOSPITALS OF LONDON.

Nulla autem est alia pro certo noscendi via, nisi quamplurimas et morborum et dissectionum historias, tum aliorum, tum proprias collectas habere, et inter se comparare.-Mobga GN De Sed. et Caus. Morb., lib. iv. Procmium.

\section{CHARING-CROSS HOSPITAL.}

TWO CASES OF ABSCESS IN THE MASTOID PROCESS; PERFORATION OF THE BONE.

(Under the care of $\mathrm{Mr}$. BARWELL.)

CASE 1. - E. F—, six years of age, was brought to the hospital with a history of severe pain in the head, which had the effect of sometimes driving her "half-mad," and at other times of producing stupefaction. She had the appearance of having borne a great deal of suffering, and looked ill ; the left ear emitted a thick discharge; the corresponding mastoid process, of which the skin was shining and reddened, was slightly swollen and exceedingly tender; the left side of the pharynx was also somewhat reddened and swollen. On the evidence of these symptoms Mr. Barwell decided to pierce the bone from behind the ear. A T-shaped incision was made over the mastoid process, and the two flaps were reflected. On the surface of the bone being then gently probed with the point of the knife, a soft spot was discovered, at which an opening was drilled with a pointed gouge. Through this some thick dark-coloured pus escaped, and some fragments of necrosed bone were removed. Mr. Barwell then scraped the carious portions of the bone until healthy tissue was reached, and plugged the wound with a piece of lint dipped in carbolic-acid lotion.

Two days later the child was free from pain and had lost her suffering appearance. She was ordered ten grains of chlorate of potassium three times a day, and was shortly afterwards discharged with instructions to keep the wound open with a plug of lint and to attend frequently at the hospital. These injunctions she did not, however, obey, and twelve days after the operation, when she was induced by a return of the pain in the head to visit the hospital, the wound was found to have closed. It was reopened with a probe, and its patency was maintained by means of a nailshaped plug of gentian-root until the thirty-sixth day after the first operation, when every indication for its continued use had disappeared.

In reference to this operation, Mr. Barwell said that abscess in the mastoid process was not an uncomrnon disease of childhood. It first found vent into the tympanum through the natural opening, but, on account of the insufficiency of this passage, it also made itself a way into the meatus externus. Sometimes the bone would become more and more affected until at length the cerebral surface became involved, and then inflammation and abscess of the brain was liable to follow. Another danger, which the proximity of the lateral sinus would explain, was the supervention of pyæmia. The position of that canal also necessitated the exercise of great caution and gentleness on the part of the operator, lest he should plunge his instrument through the inner table of the skull, more especially as in children the tissues of the mastoid process are soft, and of less comparative depth on account of the non-development of the mastoid cells.

CASE 2-The second case is of greater interest, on account of the patient having reached the comparatively mature ag'e of forty-seven, and as the premonitory symptoms were accompanied by profuse epistaxis, for which the patient, Martha $\mathrm{B}$ - was admit ed some weeks before the nature of the disease could be clearly made out.

On the occasion of her first admission, the posterior nares were plugged by the house-surgeon, Mr. Towt, and large doses of the sesquichloride of iron were administered. 'The patient was a stout, well-made woman, with a rather puffy face; but no evidence either of kidney or heart disease 